\title{
Synergistic role of prolactin and testosterone in the regulation of acid phosphatase activity and isoenzyme pattern in the accessory sex organs of adult male rats
}

\author{
S. P. Ghosh, T. K. Chatterjee and J. J. Ghosh \\ Department of Biochemistry, University College of Science, 35 Ballygunge Circular Road, \\ Calcutta 700019, India
}

\begin{abstract}
Summary. Testosterone treatment of adult castrated rats maintains the activity and isoenzyme pattern of acid phosphatase in the ventral prostate and seminal vesicle glands. However, testosterone fails to have this effect in rats hypophysectomized and castrated or in castrated rats treated with bromocriptine. Concurrent treatment with prolactin restores the normal acid phosphatase pattern, suggesting that prolactin has a synergistic role with testosterone in the regulation of acid phosphatase activity and its isoenzyme pattern in male rat accessory sex organs.
\end{abstract}

\section{Introduction}

The acid phosphatase activity of the rat ventral prostate is under androgenic control, and an isoenzyme variant of acid phosphatase that disappears after castration can be restored by testosterone treatment (Tenniswood, Bird \& Clark, 1976; Tenniswood, Abrahams, Bird \& Clark, 1978). Rennie, Bruchovsky \& Hook (1978) have demonstrated a differential response of this isoenzymic variant to low and high dose of androgen. We have now investigated the hormonal control of acid phosphatase activity in the rat ventral prostate and the seminal vesicle.

\section{Materials and Methods}

Male albino rats (Charles Foster Strain) weighing 175-200 g (6 rats in each group) and maintained on a standard diet and water ad libitum were used. Rats were anaesthetized with pentobarbitone sodium and hypophysectomized by the parapharyngeal approach and castrated by the scrotal route. The control rats were sham-operated. The animals were housed at $27^{\circ} \mathrm{C}$ with $12 \mathrm{~h}$ light $(09: 00-21: 00 \mathrm{~h}) / 24 \mathrm{~h}$.

\section{Hormone and drug treatments}

Testosterone propionate (Ciba/Geigy, India Ltd) was injected subcutaneously at a dose of 2 $\mathrm{mg} / \mathrm{kg}$. The injection vehicle was $0 \cdot 1 \mathrm{ml}$ sesame oil $\left(\mathrm{V}_{1}\right)$ and the injection was given daily for 7 days starting from the day of castration. This treatment schedule was selected on the basis of previous studies (Tenniswood et al. 1976; Ghosh, Chatterjee \& Ghosh, 1981). Ovine prolactin (National Pituitary Agency, U.S.A.) at a dose of 31.0 i.u./kg and bromocriptine (2-bromo-alpha-ergocriptine: Sandoz, India Ltd) at $2 \mathrm{mg} / \mathrm{kg}$ were administered intramuscularly (twice daily) for 7 consecutive days starting from the day of castration. The injection vehicle was $0.5 \mathrm{ml} 0.001 \mathrm{M}-\mathrm{NaHCO}_{3}\left(\mathrm{~V}_{2}\right)$ 
for ovine prolactin and $0.1 \mathrm{ml}$ ethanol $(95 \% \mathrm{v} / \mathrm{v})\left(\mathrm{V}_{3}\right)$ for bromocriptine. The vehicles were administered separately to the respective control groups in equivalent amounts and by the same route daily for 7 days.

\section{Preparation of tissue extracts}

Rats were killed $24 \mathrm{~h}$ after the final dose and the ventral prostate and seminal vesicle glands were carefully dissected out. Seminal vesicles were squeezed to remove the fluid and dried in blotting paper. Prostatic fluid was similarly removed. Weight of the tissue was recorded in an electric balance. The tissue was minced finely and homogenized $(10 \% \mathrm{w} / \mathrm{v})$ in an all-glass homogenizer in $0.9 \%(\mathrm{w} / \mathrm{v}) \mathrm{NaCl}$ at $0-4^{\circ} \mathrm{C}$. The homogenate was centrifuged at $4000 \mathrm{~g}$ for $10 \mathrm{~min}$ at $0-4^{\circ} \mathrm{C}$ and the supernatant was used as the enzyme source in the assay of acid phosphatase activity (EC 3.1.3.2). This enzyme source was frozen and thawed twice and centrifuged again at $105000 \mathrm{~g}$ for $1 \mathrm{~h}$ at $0-4^{\circ} \mathrm{C}$; the final supernatant was used as the enzyme source for gel electrophoresis study of the acid phosphatase.

\section{Assay of enzyme}

The assay mixture (final volume $1.0 \mathrm{ml}$ ) contained $0.5 \mathrm{ml} 100 \mathrm{~mm}$-sodium acetate-acetic acid buffer (pH 4.85), 0.1 ml 5 mm-p-nitrophenylphosphate (Sigma Chemical Co., St Louis, Missouri, U.S.A.) as substrate and $0.3 \mathrm{ml} \mathrm{H}_{2} \mathrm{O}$. The reaction was initiated by the addition of $0.1 \mathrm{ml}$ of the appropriately diluted enzyme source containing $200 \mu \mathrm{g}$ protein. After incubation for $1 \mathrm{~h}$ at $37^{\circ} \mathrm{C}$ in a water bath with constant shaking the reaction was terminated by the addition of $2 \mathrm{ml} 1 \mathrm{M}-\mathrm{NaOH}$ and the colour developed was measured spectrophotometrically at $415 \mathrm{~nm} 10 \mathrm{~min}$ after the addition of $\mathrm{NaOH}$. Enzyme activity was expressed as mmol $p$-nitrophenol liberated/total tissue protein/h.

\section{Polyacrylamide gel electrophoresis}

The acid phosphatase isoenzymes were separated on an anionic polyacrylamide gel as described by Davis (1964) and as modified by Ghosh et al. (1981). A 7.5\% polyacrylamide gel, pH 8.0, containing $0 \cdot 1 \%$ Triton X-100 was loaded with $100-150 \mu \mathrm{g}$ protein in a $25-50 \mu \mathrm{l}$ sample and electrophoresis was performed in $0 \cdot 1 \mathrm{M}$-Tris-glycine buffer, $\mathrm{pH} 8 \cdot 9$, with a current of $4 \mathrm{~mA}$ per tube, for $1 \mathrm{~h}$. Staining of specific acid phosphatase bands in the gels was accomplished by the technique of Pais, Mangold \& Mahoney (1974). The gel was first incubated for $30 \mathrm{~min}$ at $37^{\circ} \mathrm{C}$ in $0.05 \mathrm{M}$-sodium acetate-acetic acid buffer, $\mathrm{pH} 4.8$, and then for another $30 \mathrm{~min}$ in the same buffer containing $0 \cdot 1 \%$ each of fast Garnet GBC and alpha-naphthyl phosphate.

\section{Other analytical procedures}

Protein in the samples for enzyme assay was estimated by the folin phenol method of Lowry, Rosebrough, Farr \& Randall (1951) and total tissue protein was estimated both by the Biuret method of Gornall, Bardawill \& David (1949) and the folin phenol method (Lowry et al., 1951) using BSA (Sigma) as the standard.

\section{Results}

\section{Effect of castration of acid phosphatase}

As shown in Table 1, normal adult rat ventral prostate and seminal vesicle tissue contained significant acid phosphatase activity. The ventral prostate enzyme was resolved by polyacrylamide gel electrophoresis into 2 isoenzymic variants, one slower and one faster moving component (Pl. 1, 


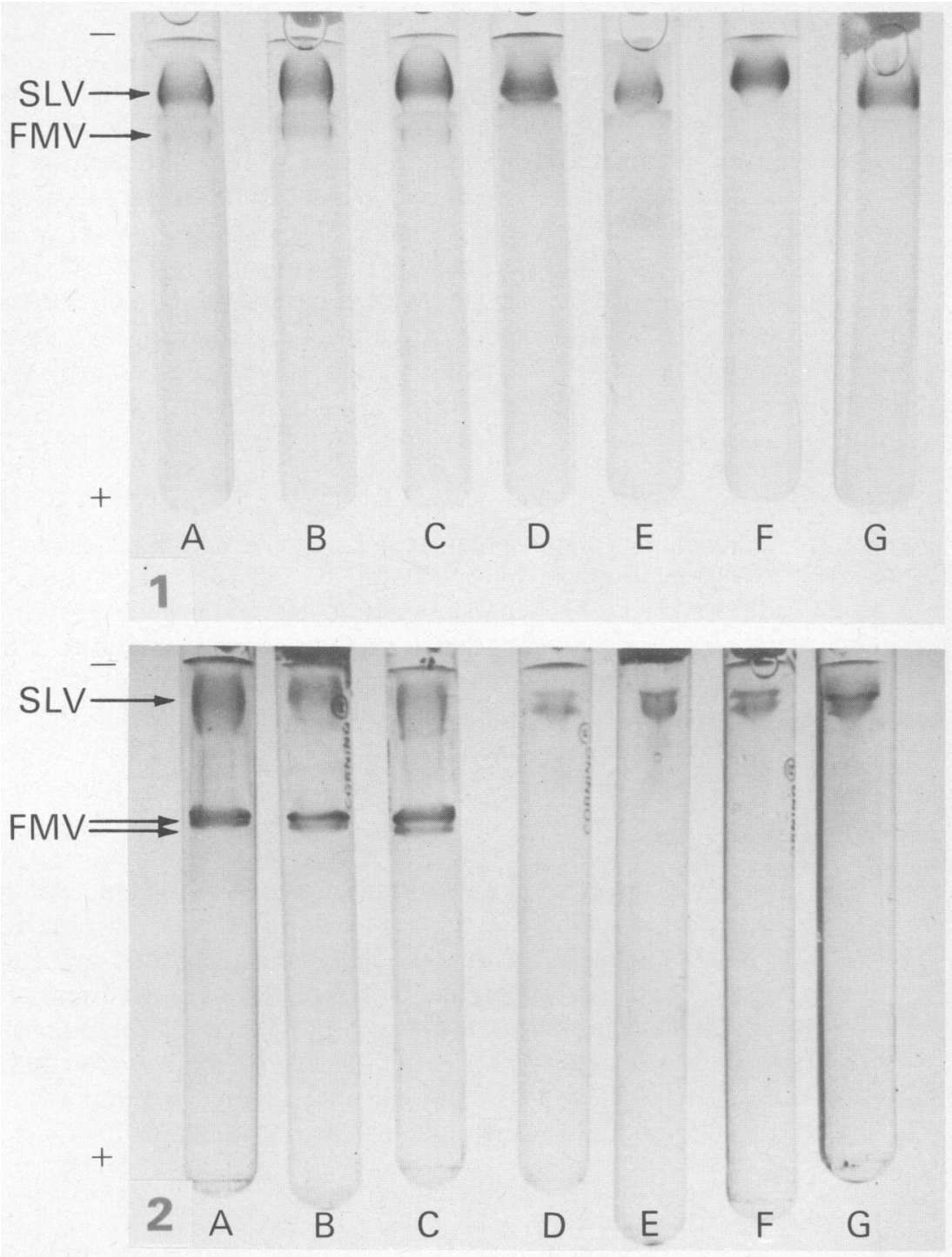

Polyacrylamide gel electrophoretic pattern of acid phosphatase in rat ventral prostate (Fig. 1) and seminal vesicle (Fig. 2) glands. Enzyme activity was localized using alpha-naphthyl phosphate as substrate and Fast Garnet GBC as the coupling agent. SLV = slowly moving variant; FMV = faster moving variant(s). (A) Intact rats; (B) testosterone-treated castrated rats; (C) castrated rats treated with bromocriptine, testosterone and prolactin; (D) castrated rats; (E) hypophysectomized-castrated rats; (F) testosterone-treated hypophysectomizedcastrated rats; $(G)$ castrated rats treated with bromocriptine and testosterone. 
Table 1. Androgenic response of acid phosphatase activity in the accessory sex organs of adult rats

\begin{tabular}{|c|c|c|c|c|}
\hline \multirow[b]{2}{*}{ Group } & \multirow[b]{2}{*}{ Surgical treatment } & \multirow{2}{*}{$\begin{array}{l}\text { Maintenance } \\
\text { drug/hormone } \\
\text { (daily for } 7 \text { days) }\end{array}$} & \multicolumn{2}{|c|}{$\begin{array}{l}\text { Acid phosphatase activity (mmol } p \text { - } \\
\text { nitrophenol liberated/total tissue protein } / \mathrm{h} \text { ) }\end{array}$} \\
\hline & & & Ventral prostate & Seminal vesicle \\
\hline 1 & Intact (sham-operated) & $v_{1}+v_{2}+V_{3}^{*}$ & $10 \cdot 29 \pm 0.84$ & $12 \cdot 32 \pm 0.92$ \\
\hline 2 & Castrated & $v_{1}+v_{2}+v_{3}$ & $3.91 \pm 0.24^{a}$ & $4 \cdot 31 \pm 0 \cdot 31^{\mathrm{a}}$ \\
\hline 3 & Castrated & Testosterone $+V_{2}+V_{3}$ & $29.09 \pm 2.01^{b}$ & $35 \cdot 57 \pm 2 \cdot 21^{b}$ \\
\hline 4 & Castrated & Bromocriptine $+V_{1}+V_{2}$ & $3 \cdot 73 \pm 0 \cdot 17^{a}$ & $4 \cdot 18 \pm 0 \cdot 22^{\mathrm{a}}$ \\
\hline 5 & Castrated & Bromocriptine + testosterone $+\mathrm{V}_{2}$ & $13 \cdot 18 \pm 0 \cdot 76^{c}$ & $12 \cdot 72 \pm 0.88^{c}$ \\
\hline 6 & Castrated & $\begin{array}{l}\text { Bromocriptine }+ \text { testosterone }+ \\
\text { prolactin }\end{array}$ & $33.61 \pm 2.02^{d}$ & $48 \cdot 58 \pm 3 \cdot 12^{d}$ \\
\hline 7 & Castrated & Prolactin $+V_{1}+V_{3}$ & $4 \cdot 02 \pm 0 \cdot 21$ & $4.84 \pm 0.38$ \\
\hline 8 & Hypophysectomy-castrated & $v_{1}+v_{2}+v_{3}$ & $3.61 \pm 0 \cdot 21^{\mathrm{a}}$ & $4.08 \pm 0 \cdot 24^{a}$ \\
\hline 9 & Hypophysectomy-castrated & Testosterone $+V_{2}+V_{3}$ & $4 \cdot 81 \pm 0 \cdot 30^{c}$ & $7 \cdot 31 \pm 0 \cdot 41^{\mathrm{c}}$ \\
\hline 10 & Hypophysectomy-castrated & Prolactin $+V_{1}+V_{3}$ & $3.97 \pm 0.22$ & $4.61 \pm 0.29$ \\
\hline 11 & Hypophysectomy-castrated & Testosterone + prolactin $+\mathrm{V}_{3}$ & $29.93 \pm 2.01^{e}$ & $44 \cdot 24 \pm 2 \cdot 15^{e}$ \\
\hline
\end{tabular}

Values are mean \pm s.e.m. for 6 different rats and were analysed by Student's $t$ test.

a Significantly different $(P<0.001)$ from values for Group 1 rats (controls).

b Significantly different $(P<0.005)$ from values for Group 2 rats.

c Significantly different $(P<0.001)$ from values for Group 3 rats.

S Significantly different $(P<0.01)$ from values for Group 5 rats.

e Significantly different $(P<0.005)$ from values for Group 9 rats.

* See text for vehicle compositions.

Fig. 1; gel A). The seminal vesicular acid phosphatase was resolved into 3 isoenzymic variants, one slower and two faster moving components (Pl. 1, Fig. 2; gel A). Castration for 7 days caused a decrease in the acid phosphatase activity in the ventral prostate (by $62 \%$ ) as well as in the seminal vesicle (by $65 \%$ ) and the disappearance of the faster moving isoenzyme variant(s) in both the tissues (P1. 1, Figs 1 \& 2; gel D).

\section{Effects of testosterone, bromocriptine and prolactin}

The reduced amount of acid phosphatase activity in castrated rats was markedly stimulated by testosterone treatment (by $743 \%$ in the ventral prostate and by $825 \%$ in the seminal vehicle), and the normal isoenzymic pattern of acid phosphatase was restored (Pl. 1, Figs 1 \& 2; gel B). However, testosterone treatment did not restore acid phosphatase activity and isoenzyme pattern in hypophysectomized-castrated rats (Pl. 1, Figs $1 \& 2$; gel F) or in castrated rats simultaneously treated with bromocriptine (Pl. 1, Figs $1 \& 2$; gel G). Ovine prolactin alone had no effect on the level of acid phosphatase or the isoenzyme pattern in hypophysectomized-castrated and castrated rats, but when prolactin and testosterone were given, values in the hypophysectomized-castrated rats were stimulated by $750 \%$ in the prostate and $960 \%$ in the seminal vesicle. Prolactin also enhanced the enzyme values in bromocriptine + testosterone-treated castrated rats ( 255 and $381 \%$ in the ventral prostate and seminal vesicles respectively) (Pl. 1, Figs $1 \& 2$; gel C).

\section{Discussion}

The decrease in acid phosphatase activity in male rat accessory sex organs after castration and the reversal of this effect of castration by testosterone treatment confirms that acid phosphatase activity in the male accessory sex organs is under androgenic control. The isoenzyme variant(s) that disappears after castration and is restored by testosterone is the faster moving variant(s).

In hypophysectomized-castrated rats, the testosterone-induced stimulation of acid phospha- 
tase in accessory sex organs was much reduced and there was no restoration of the faster moving isoenzyme variant of acid phosphatase, thus suggesting a pituitary involvement in this regulation of the androgenic control of acid phosphatase. Bromocriptine + testosterone treatment restored the enzyme activity to values in intact rats but not to those of testosterone-treated castrated rats. Since bromocriptine is reported to suppress pituitary prolactin release (Del Pozo, Brun Del Re, Vorga \& Fiesen, 1972; Corrodi, Fuxe, Hökfelt, Lidbrink \& Ungerstedt, 1973), an involvement of prolactin was considered. Treatment of castrated and hypophysectomized-castrated rats with prolactin alone had little effect but a synergistic activity was found with testosterone and with bromocriptine + testosterone.

Although the present evidence suggests a role of prolactin in the androgenic control of acid phosphatase of male accessory sex organs, the mechanism by which this hormone affects the androgenic response is not clear. Prolactin may affect the conversion of testosterone to dihydrotestosterone or the androgen binding protein/receptor level of these organs. Since hypophysectomy has been reported to have no effect on the testosterone to dihydrotestosterone conversion in the ventral prostate or seminal vesicles (Rondall \& Ebling, 1978) the former mechanism appears less likely.

We thank the Indian Council of Medical Research, New Delhi and Kothari Scientific \& Research Institute, Calcutta for financial assistance; and Dr Salvatore Raiti, Director, National Pituitary Agency, Baltimore, U.S.A., for kindly supplying pure ovine prolactin.

\section{References}

Corrodi, H., Fuxe, K., Hökfelt, T., Lidbrink, P. \& Ungerstedt, U. (1973) Effect of ergot drugs on central neurons: evidence for a stimulation of central dopamine neurons. $J$. Pharm. Pharmac. 25, 409-410.

Davis, B.J. (1964) Disc electrophoresis. III. Method and application to human serum proteins. Ann. N.Y. Acad. Sci. 121, 404-427.

Del Pozo, E., Brun Del Re, R., Vorga, L. \& Fiesen, H. (1972) The inhibition of prolactin secretion in man by CB-1 54 (2-Br- $\alpha$-ergokryptine). J. clin. Endocr. Metab. 35, $768-771$.

Ghosh, S.P., Chatterjee, T.K. \& Ghosh, J.J. (1981) Antiandrogenic effect of delta-9-tetrahydrocannabinol in adult castrated rats. J. Reprod. Fert. 62, 513-517.

Gornall, A.G., Bardawill, C.J. \& David, M.M. (1949) Determination of serum protein by means of the biuret reaction. J. biol. Chem. 177, 751-755.

Lowry, O.H., Rosebrough, N.J., Farr, A.L. \& Randall, R.J. (1951) Protein measurement with the folin phenol reagent. J. biol. Chem. 193, 265-275.
Pais, W.M., Mangold, A.W. \& Mahoney, S.A. (1974) Fractionation and purification of prostatic acid phosphatase. Invest. Urol. 12, 13-16.

Rennie, P.S., Bruchovsky, N. \& Hook, S.L. (1978) Androgenic regulation of a tissue specific isoenzyme of acid phosphatase in rat ventral prostate. J. Steroid Biochem. 9, 585-593.

Rondall, V.A. \& Ebling, F.J. (1978) The effect of hypophysectomy on the in vivo metabolism of testosterone in the skin and other tissues of the rat. J. Steroid Biochem. 9, 826-827.

Tenniswood, M.P., Bird, C.E. \& Clark, A.F. (1976) Acid phosphatase: androgen dependent markers of rat prostate. Can. J. Biochem. 54, 350-357.

Tenniswood, M.P., Abrahams, P.P., Bird, C.E. \& Clark, A.F. (1978) Effect of castration and androgen replacement on acid phosphatase activity in the adult rat prostate gland. J. Endocr. 77, 301-308.

Received 11 August 1982 